\title{
An Analysis of Aldo Leopold's Land Ethics
}

\author{
Yonggang Zhao \\ School of Foreign Languages, China West Normal University \\ No. 1 Shi Da Road, Nanchong, 637009, Sichuan, China
}

\begin{abstract}
Since the 1970s, the global ecological crisis has become increasingly serious and people have to rethink the relationship between man and nature. In this process of reflection, Leopold's land ethics, which had been neglected, have been re-examined and gradually accepted. Based on the non-anthropocentrism, Leopold's land ethics puts forward the methodology of ecological holism to solve the problem of environmental crisis. This paper attempts to study Leopold's land ethics, and to analyze its causes, introduce its content, and appraise its ideological characteristics.
\end{abstract}

Keywords: Aldo Leopold; Land Ethics; source; contents; characteristics.

\section{INTRODUCTION}

With the continuous deterioration of the natural environment, human beings are already in a very serious ecological crisis. Faced with this situation, American scholar Aldo Leopold (1887-1948) puts forward the Land Ethics from the view of constructing the relationship between human beings and nature in the 1930s. It has become an important theoretical resource to guide the contemporary environmental movement, and it is of great significance to guide people to correctly understand and alleviate the current ecological crisis. Aldo Leopold is a famous American ecologist and environmental protection pioneer, known as "the founder of American new environment theory", "the father of ecological ethics", and "the originator of wildlife management". His Land Ethics regard nature as a whole, which including soil, water, air, animal and human. He thinks that human and other species in nature are the ordinary members of the whole. His thoughts fundamentally expand the scope of ethical values and affirm the intrinsic value of life, and greatly promote the emergence and development of ecology and environmental ethics. At the same time, the Land Ethics has changed the traditional concept of anthropocentrism, established a new concept of ecological holism, and promoted the rise of the American environmental movement in the 1960s and 1970s, and became the important guiding ideology of its practice. From the social background of Leopold's Land Ethics, this paper explains the objective inevitability of this thought, and then discusses the connotation of Leopold's Land Ethics, and finally makes a general evaluation of it.

\section{THE FORMATION BACKGROUND OF LEOPOLD'S LAND ETHICS}

The formation and development of Leopold's Land Ethics has a certain theoretical foundation, and is the product of a particular time. It makes sharp criticism to the traditional anthropocentrism, but at the same time it absorbed the western ecological view and previous advanced ecological thought. The transformation of his thought is closely related to the development of science and technology at that time, and to the educational and family backgrounds he was subjected to.

\subsection{Social Background}

Leopold lived in the frenetic era of economic development in the United States. The material resources needed for economic development were mainly extracted from the natural resources of the country. People deeply conquered nature and used natural resources, and at the same time brought the ecological crisis. Especially after the $1860 \mathrm{~s}$, American industry is increasingly developed, and gradually replaced the British industry and acquired a monopoly in the world. The gross annual value of its industrial output accounted for one third of the world, which ranked first in the world. However, these industries are based on the consumption of natural resources for development, resulting in the consequences of natural resources were severely damaged and wasted. The U.S. Government didn't 
implement the related land protection policy while launching the market economy policy, which lead to the uncontrolled development of the land reclamation and resources exploitation. Yet at that time, most Americans are naive to think that America has vast territory and abundant resources, and they did not realize that the consequences of the changes in the ecological environment will be extremely serious. Until the late nineteenth century, some prescient scientists and intellectuals had become aware of the changes in the ecological environment and expressed deep concern about its continued development. They began to publish a large number of articles to expound the relationships between the development of human society and the change of natural environment, and tried to call on the government to take appropriate measures to protect natural resources, and also hope to improve the broad masses of environmental awareness. The cruel situation makes an increasing number of people began to worry about the future of the ecological environment and intellectuals began to illustrate their own opinion of view. The U.S. government has also begun to pay attention to it and take measures to strengthen the management of natural resources. At the same time, the Protection Act provided a favorable political environment for the development of the environmental movement in the United States. That's the context of the growth of Leopold. After entering the 1960s, Leopold's Land Ethics came into people's eyes. His ideas in the book Sand County Almanac were gradually accepted by people. People started to focus on the social living environment, not just immersed in the great wealth which brought by the rapid development of science and technology.

\subsection{Theoretical Background}

The creation of Leopold's Land Ethics is based on certain philosophical theory, which mainly includes the following three aspects: First, the value theory of philosophy; Second, the criticism of anthropocentrism; third, the ecological idea of Christianity.

First, it is based on the value theory of philosophy. Leopold's thinking on the value theory of philosophy is mainly reflected in two aspects: one is thinking as a mountain--eco-holism which takes the mountain as the object, linking animals, plants and rocks together, so that it has the integrity. This is the main purpose of Leopold's thinking. People tend to start from the view of utilitarian to protect mountain animals, but they ignore the existence of the wolf and the integrity of ecology, and the erroneous ecological concepts will have an adverse impact on the ecosystem. By discussing the "useless" of wild animal protection, Leopold explained the contents of eco-holism. The other one is the recognition of the wilderness value of the philosopher Muir's thought. Muir was revered as "the father of the American National Park" and played an important role in proving the value of the wilderness and defending the ideals of the national park. He advocated respect for all things in nature, and put forward the "nature has the right" thought, that any individual of the natural world has the right not to be violated. People cannot build their own rights on the violation of other individual organism. As long as organism exists, people must respect and protect their rights to exist, and shouldn't destroy plants or kill animals. For example, he believes that the wilderness is not without the use of value, but a complete ecosystem, and its existence provides a habitat for the survival and growth of some plants and animals. Leopold absorbed Muir's thought of protecting the wild animals and attaching importance to the value of the wilderness, which provided the theoretical basis for the formation of his land ethics.

Second, it is based on the criticism of anthropocentrism. Leopold's land ethics is based on the criticism of anthropocentrism. Anthropocentrism advocates that human beings are the core of all social relations. And there is no doubt that the natural environment is a subsidiary product which outside the relationship between man and society. For a long time, people only consider the problem from the human point of view, and there is almost no consideration of the natural environment and ecological protection. They believe that human beings have the right to conquer nature and transform nature without any restriction. Under the long-term influence of this thinking, people waste resource and destroy it, so it caused not only environmental deterioration but also the imbalance of the ecosystem. Leopold hold a negative and critical attitude on anthropocentrism, he advocated that the human should reasonably use natural resources and must protect it, which is a great subversion to traditional anthropocentrism. His land ethics regard man and nature as a unitary whole and ask people to expand the scope of the moral community, change the original idea of anthropocentrism and let people change their roles, that is to say, people must shift the identity from the leader and conqueror to an ordinary member of a biological system, so as to make the entire ecosystem runs well. 
Third, it is based on the ecological idea of Christianity. Religion is an indispensable factor in human civilization. There is also religious color in the concept of ecology, especially because Christianity has great influence on social life and ideology. So its ecological concept has played an important role in the formation of people's ecological values. Christianity advocated the re-establishment of ecological concepts between mankind and nature, the most famous of which is the green movement. Thus the status of Christianity in environmental protection is becoming increasingly obvious and it has an important influence on the later scholars. For example, White pointed out that the moral community has no boundary restrictions; J. Moltmann created the ecological creation theory and Leopold critically accepted these thoughts when he studied ecological problems, which has played an important role in the construction of the eco-holism. Therefore, the ecological idea of Christianity is also one of the important theoretical bases of the land ethics.

\section{The MAIN CONTENT OF LEOPOLD'S LAND ETHICS}

Land ethics is the essence of Leopold's thought. According to the evolution of land ethic, he divided his content into the evolution order of ethics, the concept of community, the consciousness of ecology and so on.

\subsection{The Evolution Order of Ethics}

Under the influence of anthropocentrism, people used to classify the species according to their own needs, and evaluate the merits and merits, give different values to them and treat them with different attitudes. In practice, people often use the economic scale to measure the value of environmental protection. They only emphasized the contribution of natural environment to human beings, and completely ignore the harmonious relationship between human and nature. Leopold argued that individual characteristics are not considered in the existence of biological individual, and we must make people fully aware of the existence of each biological individual in the entire ecological chain are playing their respective functions, and we can't value them by their contributions to humanity. He believes that people should not completely from the economic point of view to consider how to use and protect nature, because the purely economic interest-driven behavior will leave the natural ecosystem in a shambles and destroy the integrity and functionality of the whole system. Through the combination of ethics and ecology thought, he puts forward the ecological evolutionary thought of human ethical relationship, and holds that the orderly evolution of human ethics can be divided into three stages, including the initial ethical stage of the relationship between human beings, the ethical stage of the relationship between man and society, and the ethical stage of the relationship between man and social community. The division of these three stages follows the evolving process of ecological evolution. He believes that ethics should not only be limited in human society to deal with the relationship between people or the between people and society, but also should be applied to deal with the relationship between human and nature. He advocated that we must hold an "ecological conscience" to the natural environment and have a sense of moral responsibility for the management and maintenance of it, and we can't destroy ecology just because we master technology to conquer and transform nature.

\subsection{The Concept of Community}

Leopold called sand the "land community" in Sand County Almanac, the concept of land here does not simply refer to humans and other organisms live in the land, but also includes plant, animal, air and water etc. All these constitute an organic unity, but also can regard the organisms on the earth as an organ of ecosystem, and bear the function of the ecological system to play a normal role. "Land community" contains two meanings. First, the land is not only including the soil, but also includes the animal, plant and water, air, climate and so on. In essence, Leopold's land community has been extended to the whole nature. Nature is a community, but also a living organism. The purpose of Leopold's extension of the concept of community is to let mankind know that nature has a life and that any living thing has the right to survive. Second, people are members of the land community, emphasizing the equal relationship between man and nature is no longer a master-servant relationship, but a partnership. Thus the land ethics transforms the role of mankind from the conqueror of the land community into the ordinary members and citizens therein. It contains respect for its fellow members and the community. In this way, it subverts the relationship between man and nature. By changing the status of man in nature, "Land community" concept gives the ethical code to all the existence in nature, so as to give them the right to exist. 


\subsection{Ecological Awareness}

Leopold advocated establishing an ethical sense of ecology, so that make people extend the social consciousness to the ethical consciousness, and extend the problem from the intellectual category to the inner emotional category. In his view, it's not difficult to let people produce a sense of resource protection; the difficulty is the real implementation and effectiveness. For example, in many cases, by strengthen the education of resource protection or by law, vote, and even by participate in some resource protection organizations. All of this cannot fundamentally solve the increasingly serious environmental and resource problems, and even has never achieved satisfactory results. This is due to the lack of ecological awareness, so it becomes an empty talk.

\section{THEORETICAL Significance OF LeOPOLD'S LAND ETHICS}

Leopold's land ethics is of great significance in two aspects.

First, it broadens the field of ethical theory. The land ethics puts forward a kind of ecological ethic thought for mankind, it is a great revolution in the field of ethics, and promoted the development of environmental ethics at the same time. Leopold believed that human beings should extend the boundary of moral ethics, and put the whole nature into the scope of human ethics. The land ethics has changed mankind's understanding of the relationship between man and nature. This new thought has provided a new perspective for the exploration of nature, which laid the foundation for the emergence and development of new environmental ethics, and affected a large number of scholars. For example, P. Taylor extends the ethical investigation of the relationship between man and nature to the whole biological world by referring to the extension of ethics in Leopold's land ethics; On the basis of Leopold values, Holmes Rolston, a professor of Colorado in U.S., has founded the overall value of the natural system; The deep ecology, represented by the Norwegian philosopher Arne Naess, absorbs the evaluation criteria of human behavior and the holistic ecological view in the land ethics. It proposed the evaluation of human behavior from the perspective of the biosphere as a whole, especially the man-made environmental pollution.

Secondly, it constructs a new ecological world view. Leopold's land ethics has broken through the thought that man is the biosphere leader, and has shown a kind of ecological world outlook. This ecological worldview focuses on all components of the ecosphere: human, nonhuman, mountains, rivers, forests, wetlands and everything on earth. Leopold believes that there is an interaction between species and environment within the ecosystem. On the one hand, the environment determines the existence and development of species, providing material, energy and space for the survival of species. On the other hand, the activities of the species will have an impact on the environment. Species and the environment are interdependent. Species and the environment are interdependent. He emphasized the interrelationships between human and the natural environment. This is different from the mainstream ideas in human history. The mainstream ideas emphasize human ecology, human nature, and human world. And Leopold's land ethics advocated that the ecology is the existence of all the species' living conditions and their mutual relations. The establishment of the ecological world view of the coexistence of human and other non-human beings in the whole ecological environment has find the way to alleviate the contradiction between economic development and environmental damage, not only points out the way to deal with the relationship between human and nature, but also the direction for the long-term development of human beings.

\section{CONCLUSION}

Leopold's land ethics has remained the most extensive influence since the new environmental movement in the 1960s, and this influence has been increasing with time, fully demonstrating its intrinsic value and significance. It was in keeping with the values of the times, and so many people think that Leopold's land ethics was now more important than he conceived.

\section{REFERENCES}

[1] Aldo Leopold. A Sand County Almanac and Sketches Here and There[M].New York: Oxford University Press, 1949.

[2] Aldo Leopold. A Sand County Almanac: With Other Essays on Conservation from Round River [M]. Oxford University Press, 1966. 
[3] Aldo Leopold, John Muir, and the Importance of Community [J].The journal of environmental education, 2011, 42(3)

[4] D. E. Marietta, Ethical Holism and Individuals [J]. Environmental Ethics.1988, 10.

[5] HOLMES ROLSTON III. The land ethic at the turn of the millennium [J]. Biodiversity and conservation, 2000, 9(8)

\section{AUTHOR's BIOGRAPHY}

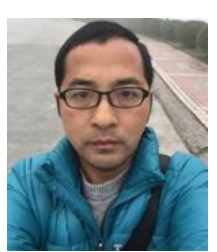

Zhao Yonggang, Ph. D., a associate professor at the College of Foreign Language, China west Normal University (Nanchong, 637009). His major research interest is Anglo-American literature.Email: zhyg007@163.com. 